\title{
Salvage immunotherapy for fulminant pseudomembranous colitis
}

\author{
Salman Abdulaziz, ${ }^{1}$ Nabil Abou-Shala, ${ }^{1}$ Ashraf Al-Tarifi, ${ }^{1}$ Rashid Amin ${ }^{2}$
}

${ }^{1}$ Department of Adult Critical Care Medicine, King Faisal Specialist Hospital and Research Center, Riyadh Saudi Arabia ${ }^{2}$ Formulary Management Committee, King Faisal Specialist Hospital and Research Center, Riyadh, Saudi Arabia

\section{Correspondence to} Dr Salman Abdulaziz dr-salman@hotmail.com
To cite: Abdulaziz S, AbouShala N, Al-Tarifi A, et al. BMJ Case Rep Published online: [please include Day Month Year] doi:10.1136/ bcr-2013-008786

\section{DESCRIPTION}

A 49-year-old man was admitted to the intensive care unit (ICU) for septic shock secondary to

Table 1 Patient's laboratory results at presentation to the intensive care unit

\begin{tabular}{|c|c|c|}
\hline Complete blood count & Normal range & Results \\
\hline White cell count & $3.9-11 \times 10^{9} / 1$ & $48.2 \times 10^{9} / 1$ \\
\hline Haemoglobin & $135-180 \mathrm{~g} / \mathrm{l}$ & 73 \\
\hline Platelet & $155-435 \times 10^{9} / 1$ & 443 \\
\hline \multicolumn{3}{|l|}{ Renal chemistry } \\
\hline Blood urea nitrogen (BUN) & $2.5-7.5 \mathrm{mmol} / \mathrm{l}$ & 14.0 \\
\hline Creatine & $64-115 \mu \mathrm{mol} / \mathrm{l}$ & 235 \\
\hline Sodium & $\begin{array}{l}135- \\
147 \mathrm{mmol} / \mathrm{l}\end{array}$ & 130 \\
\hline Potassium & $3.5-5 \mathrm{mmol} / \mathrm{l}$ & 4.6 \\
\hline Chloride & $98-111 \mathrm{mmol} / \mathrm{l}$ & 94 \\
\hline Bicarbonate & $22-31 \mathrm{mmol} / \mathrm{l}$ & 18 \\
\hline Magnesium & $0.7-1 \mathrm{mmol} / \mathrm{l}$ & 0.85 \\
\hline lonised calcium & $\begin{array}{l}1.13- \\
1.32 \mathrm{mmol} / \mathrm{l}\end{array}$ & 0.76 \\
\hline Phosphorus & $\begin{array}{l}0.7- \\
1.45 \mathrm{mmol} / \mathrm{l}\end{array}$ & 2.56 \\
\hline \multicolumn{3}{|l|}{ Venous blood gas } \\
\hline $\mathrm{pH}$ & $7.30-7.40$ & 7.30 \\
\hline $\begin{array}{l}\text { Mixed venous oxygen } \\
\text { saturation (SVO2) }\end{array}$ & $60-80 \%$ & $60 \%$ \\
\hline Lactic acid & $0.05-2 \mathrm{mmol} / \mathrm{l}$ & 4.0 \\
\hline \multicolumn{3}{|l|}{ Other blood chemistries } \\
\hline Procalcitonin & $<0.5 \mathrm{ng} / \mathrm{ml}$ & 3.21 \\
\hline Albumin & $32-48$ g/l & 27 \\
\hline Billirubin & $0-21 \mu \mathrm{mol} / / \mathrm{l}$ & 197 \\
\hline
\end{tabular}

Clostridium difficile infection (CDI) complicated with severe pseudomembranous colitis. His medical history was remarkable for glossectomy, proximal esophagectomy and gastric pull-up for recurrent laryngeal cancer. Two weeks prior to his ICU admission, he was treated with a 10-day course of intravenous ceftazidime for line-related sepsis, after which he had several bouts of green watery diarrhoea. CDI was confirmed by positive stool cytotoxin A immunoassay, with persistent diarrhoea despite 21 days of oral metronidazole. The patient was afebrile, with a blood pressure (BP) of 88 / $54 \mathrm{~mm} \mathrm{Hg}$ and heart rate $126 / \mathrm{min}$. He was anuric with non-tender distended abdomen. Pertinent laboratory data are shown in table 1 .

Early goal-directed therapy was initiated by aggressive fluid resuscitation, packed red cells transfusion and administering dopamine. Antibiotics were upgraded to oral vancomycin $500 \mathrm{mg}$ every $6 \mathrm{~h}$, in addition to intravenous metronidazole $500 \mathrm{mg}$ every $8 \mathrm{~h}$ and intravenous meropenem $500 \mathrm{mg}$ every $24 \mathrm{~h}$. CT of the abdomen showed thickening of the colonic wall, but no megacolon or perforation was reported (figure 1). Sigmoidoscopy and biopsy showed the typical inflammatory lesions of pseudomembranous colitis (figures 2 and 3). The patient was referred to colorectal surgery for possible colectomy, which has been shown to be beneficial in fulminant CDI cases. ${ }^{1}$ However, owing to his multiple comorbidities, colectomy was not considered. After 3 days of medical treatment, intravenous immunoglobulin (IVIG) $400 \mathrm{mg} / \mathrm{kg}$ for 5 days was added to treat his colitis, in addition to bowel rest. Patients with CDI-associated diarrhoea usually have low levels of

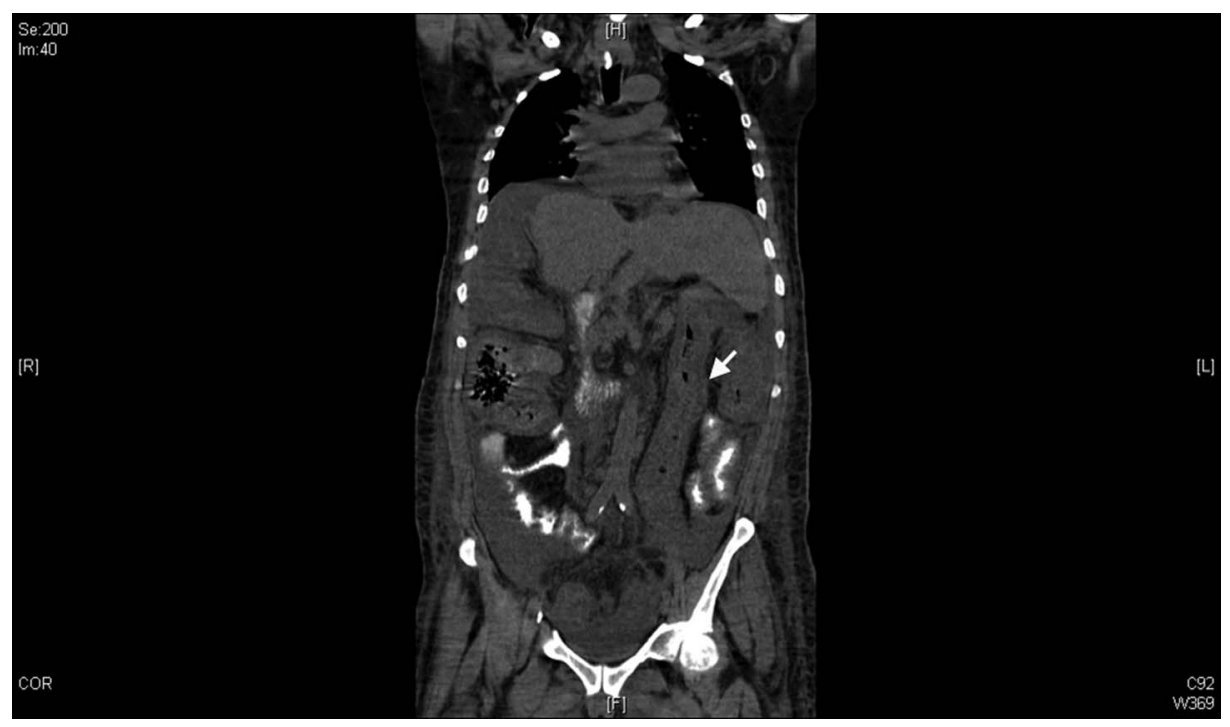

Figure 1 Abdominal CT without intravenous contrast enhancement showing colonic wall thickening. 
Figure 2 (A and B) Sigmoidoscopy picture showing typical multiple polypoid lesions of yellow colour with friable inflamed mucosa.
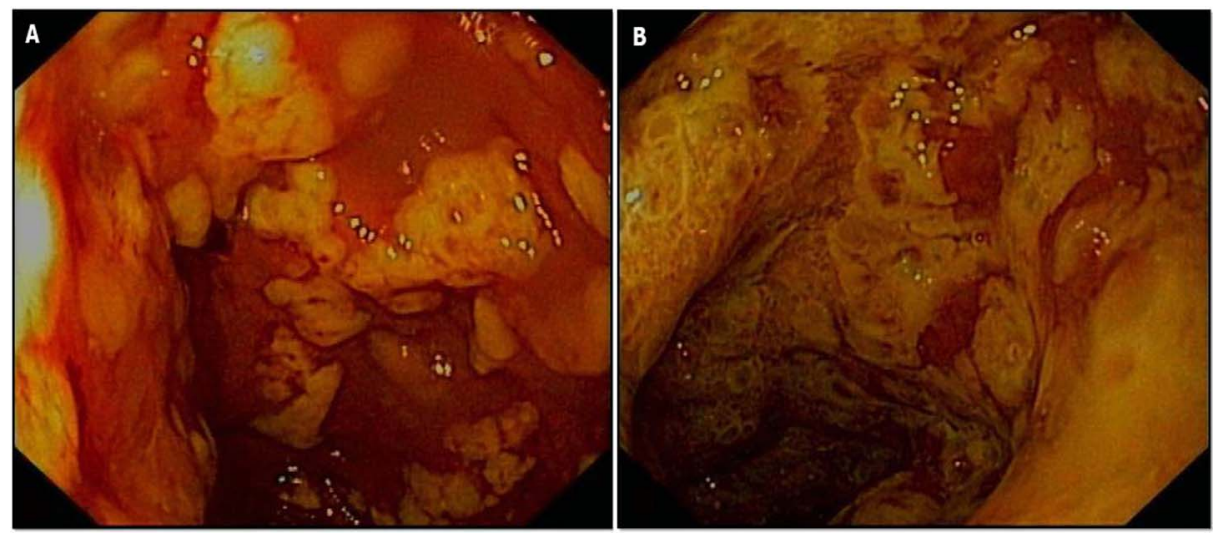

serum antitoxin IgG. ${ }^{2}$ The use of IVIG was supported by the literature, as a proven treatment modality in the treatment of severe pseudomembranous colitis associated with CDI. ${ }^{3}$ After the patient had finished the course of IVIG, his haemodynamic status and symptoms improved significantly, and he was subse-

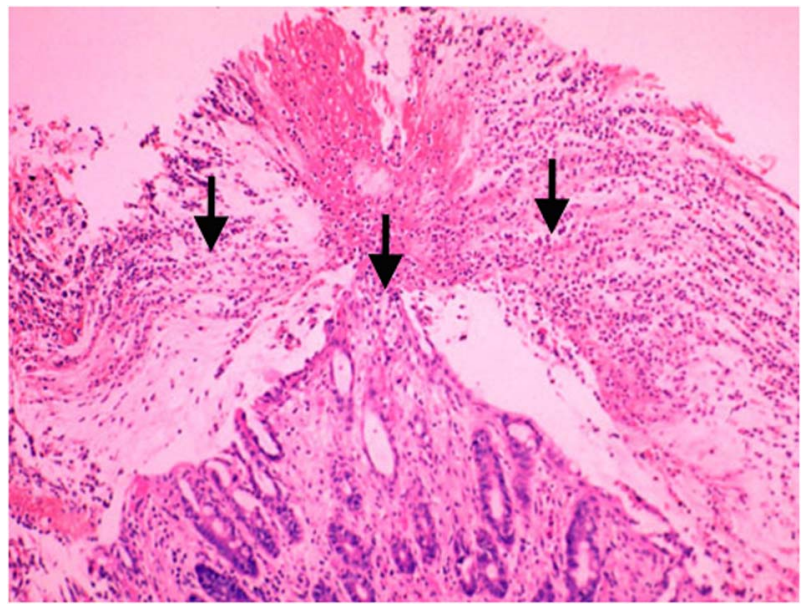

Figure 3 Histopathological examination of sigmoid colon biopsy showing neutrophilic infiltrate in the lamina propria pouring to the surface epithelium like an angry volcano. No features suggestive of bowel ischaemia (H\&E). quently transferred to the general medical ward. Oral vancomycin was stopped after a 14-day course, with no relapse of the bowel infection.

\section{Learning points}

- Clostridium difficile infection (CDI) can present with severe colitis complicated by multiorgan failure.

- Intravenous IgG might facilitate recovery of the disease and avoid surgery together with standard therapy to help manage severe CDI and may result in less recurrence of CDI.

Competing interests None.

Patient consent Obtained.

Provenance and peer review Not commissioned; externally peer reviewed.

\section{REFERENCES}

1 Koss K, Clark MA, Sanders DS, et al. The outcome of surgery in fulminant Clostridium difficile colitis. Colorectal Dis 2006:8:149-54.

2 Abougergi MS, Broor A, Cui W, et al. Intravenous immunoglobulin for the treatment of severe Clostridium difficile colitis: an observational study and review of the literature. J Hosp Med 2010:5:E1-9.

3 McPherson $\mathrm{S}$, Rees $\mathrm{CJ}$, Ellis $\mathrm{R}$, et al. Intravenous immunoglobulin for the treatment of severe, refractory, and recurrent Clostridium difficile diarrhea. Dis Colon Rectum 2006;49:640-5.

Copyright 2013 BMJ Publishing Group. All rights reserved. For permission to reuse any of this content visit http://group.bmj.com/group/rights-licensing/permissions.

BMJ Case Report Fellows may re-use this article for personal use and teaching without any further permission.

Become a Fellow of BMJ Case Reports today and you can:

- Submit as many cases as you like

- Enjoy fast sympathetic peer review and rapid publication of accepted articles

- Access all the published articles

- Re-use any of the published material for personal use and teaching without further permission

For information on Institutional Fellowships contact consortiasales@bmjgroup.com

Visit casereports.bmj.com for more articles like this and to become a Fellow 